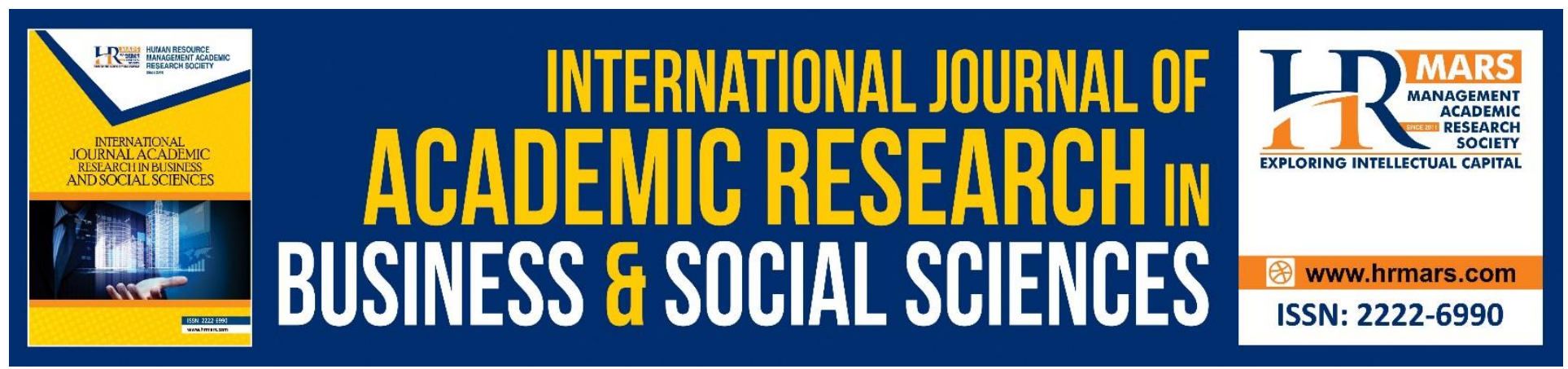

\title{
Distraction in Communication During Discussion
}

\section{Nur Maisarah Roslan, Normaliza Abd Rahim and Nur Widad Roslan}

To Link this Article: http://dx.doi.org/10.6007/IJARBSS/v10-i10/7730

DOI:10.6007/IJARBSS/v10-i10/7730

Received: 05 August 2020, Revised: 24 August 2020, Accepted: 17 September 2020

Published Online: 23 October 2020

In-Text Citation: (Roslan, Abd Rahim, and Roslan, 2020)

To Cite this Article: Roslan, N. M., Abd Rahim, N., and Roslan, N. W. (2020). Distraction in Communication During Discussion. International Journal of Academic Research in Business and Social Sciences. 10(10), 444-452.

Copyright: (C) 2020 The Author(s)

Published by Human Resource Management Academic Research Society (www.hrmars.com)

This article is published under the Creative Commons Attribution (CC BY 4.0) license. Anyone may reproduce, distribute, translate and create derivative works of this article (for both commercial and non-commercial purposes), subject to full attribution to the original publication and authors. The full terms of this license may be seen at: http://creativecommons.org/licences/by/4.0/legalcode

Vol. 10, No. 10, 2020, Pg. 444 - 452

http://hrmars.com/index.php/pages/detail/IJARBSS

JOURNAL HOMEPAGE

Full Terms \& Conditions of access and use can be found at http://hrmars.com/index.php/pages/detail/publication-ethics 


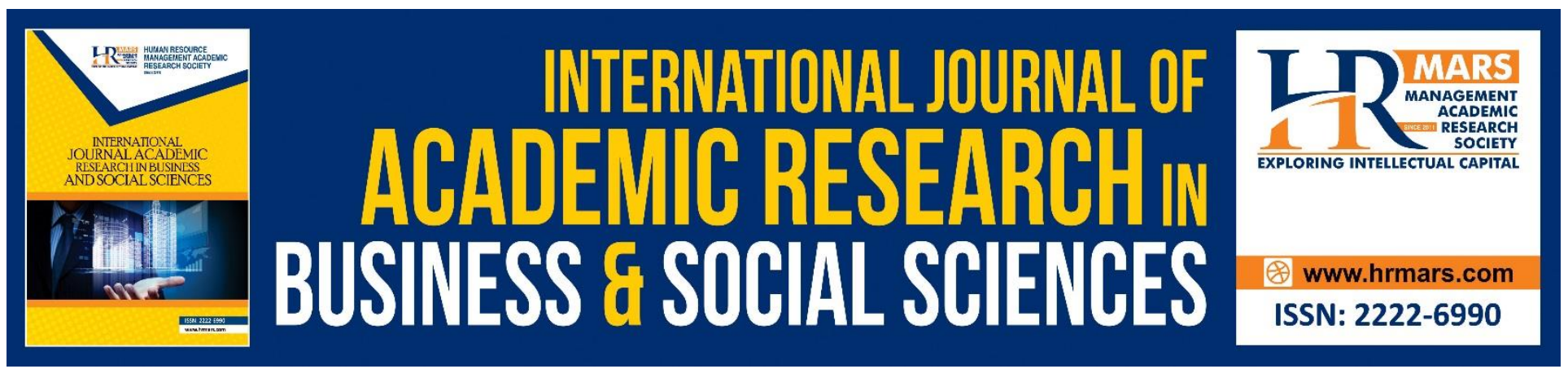

\title{
Distraction in Communication During Discussion
}

\section{${ }^{1}$ Nur Maisarah Roslan, ${ }^{2}$ Normaliza Abd Rahim and ${ }^{3}$ Nur Widad Roslan}

${ }^{1}$ Faculty of Modern Languages and Communication, Universiti Putra Malaysia, UPM 43400 Serdang, Selangor, Malaysia, ${ }^{2}$ Department of Malay Language, Faculty of Modern Languages and Communication, Universiti Putra Malaysia, UPM 43400 Serdang, Selangor, Malaysia, ${ }^{3}$ Faculty of Modern Languages and Communication, Universiti Putra Malaysia, UPM 43400 Serdang, Selangor, Malaysia

Email: 1maisaroslan@gmail.com, 2nliza@upm.edu.my and ${ }^{3}$ widad.roslan@gmail.com

\begin{abstract}
Communication involves taking part in a discussion in order to learn, to help other people learn, to examiner issues, to share ideas, and to listen to the ideas and points of view of others. A discussion involves interaction among group members, a willingness to share ideas, and a willingness to respect others' points of view. In other word, successful discussion involves leading and following, agreeing and disagreeing, contributing and questioning, exploring, expanding and focusing, evaluating, linking, responding, crediting, appreciating, and enjoying. However, distractions may happen in communication during discussion due to certain behaviours such as dominating, attacking, sarcasm about group members or their ideas, ridiculing, excluding, non-participation, lack of preparation, and often single-minded focus on task and many more. Therefore, this paper focuses on distraction in communication among secondary school students. The objectives of the study were to identify the theme and discuss the distraction during interaction. The samples of the study consisted of twelve subjects from a secondary school. The subjects were divided into groups of fours. They were given a task on storyboard for a video clip production. The activity took place in six weeks for three hours a week. The results of the study revealed that the subjects had given positive impact towards learning where they were actively involved in the task given.
\end{abstract}

Keywords: Communication, Distraction, Interaction, Learning, Discussion.

\section{Introduction}

Communication in a classroom is very crucial for teenagers in building up their self-esteem and towards better learning environment. Students communicate in order to express themselves and to not bottle-up when they were stress or in a bad mood. Other than that, communication has given a positive impact towards better learning when students were given the opportunity to speak and say whatever crosses their minds and also in a positive way. This way the teenagers were not left behind in giving ideas and chances in the learning environment. Distraction, disturbances and conflicts in 
INTERNATIONAL JOURNAL OF ACADEMIC RESEARCH IN BUSINESS AND SOCIAL SCIENCES Vol. 10, No. 10, 2020, E-ISSN: 2222-6990 @ 2020 HRMARS

communication have taken place in group discussion no matter among children, teenagers, students and adults (Hill, 2009). The distraction, disturbances and conflicts were either taken positively or negatively by the communicators and the end product of the discussion would be based on the positive impact of the communication. A large number of researches on communication were taken place in the world and the results of the research were able to give positive impact towards learners.

According to Rahim (2020c), various ways of research were conducted for the purpose of problem solving and the results can be shared among the audience who want reform in life. Various methods and theories are applied so that the study can be done well and smoothly. This study relates to the study by Rahim et al. (2020) where others views towards learning as well as the climate change has literally affect their style in learning. Rahim (2019a) agreed whereby different style of learning will create a better learning environment. Rahim (2019b) study is similar where climate change has made learners learn better in the new environment. Changes in learning gives an impact on distraction in communication among students in the classroom. Mansor and Rahim (2019) mentioned that the use of social media in education is seen as an attractive platform to improve student education. Rahim (2020b) agreed where the use of digital technology is worldwide nowadays. Therefore, the use of digital technology can give a big impact on students' education learning in the classroom. For instant, in digital technology learning, values and culture in Malay folklore animation were integrated. Rahim and Harun (2016) and Rahim et al. (2016) agreed with that where Malay folklore songs has given positive impact on students' perceptions and Malay folklore interests all type of students and it gives an impact towards their knowledge of Malay folklore.

Distractions in communication were based on the interpersonal communication of a speaker. According to Devito (2009) there were psychological processes in order to have interpersonal communication and the communication was arose from the culture of the person. Floyd (2008) stated that although most interpersonal communication texts were based through perception, language, and

relationships, this text broadens and the advantages and disadvantages of communication will be experienced by the learners. Devito (2009) postulates that unless the specific features of communication are covered, such as verbal and nonverbal cues, as well as the types of relationships and contexts in which interpersonal communication will occur. Wood (2010) states that interpersonal communication will be actively involved when two or more speakers communicate in the same topic. Therefore, the relationship between speakers play an important role in communication. Tingley et al, (2006) argue that unless the topic of conversation was agreed among the speakers, therefore there will be a positive outcome in a communication. Braedyn et al. (2010) agreed to the statement by Tingley et al, (2006) and stress that there will be disturbance in communication if there were disagreement in the topic of communication.

Rahim (2011a) states that disturbance in storytelling among children has helped the children in giving brilliant ideas and actively involved in the storytelling session. The study involved 10 subjects and the subjects aged between 7-9 years old. The subjects were story told by the teacher and there were disturbances during the storytelling session. The disturbances were able to help the children in giving ideas and create an active storytelling environment. Abigail and Cahn (2011) agree with Rahim 
INTERNATIONAL JOURNAL OF ACADEMIC RESEARCH IN BUSINESS AND SOCIAL SCIENCES Vol. 10, No. 10, 2020, E-ISSN: 2222-6990 @ 2020 HRMARS

(2011a) and postulate that in order to resolve conflict or disturbances in communication, students were given the chance to speak-up and hence the learning environment will be interesting.

Cahn (2006) claims that managing conflict or distraction in communication will be done concurrently with learning where a person who has the conflict or distraction will need use the conflict or distraction as a stepping stone to better learning environment. Rahim (2011b) agrees with the statement by Cahn (2006) where the distraction among focus group learners' of media need be taken place in order for the learners to be actively involved and give new ideas towards the project. The study by Rahim (2011b) investigates the communication that took place while creating and writing storyboard for a music video clip among focus group learners of media at a secondary school in Nottingham United Kingdom. The subjects involved were five pairs of subjects aged between 16-18 years old at one of the colleges in Nottingham United Kingdom. A task was given to each pair and the length of time for them to discuss about the layout and the content of the storyboard was 3 hours for each pair in five weeks. The discussion will be taped and analyzed accordingly. The results of the study revealed that the subjects were actively involved in the study and they collaborated well until the end of the fifth week of the study.

Another study by Rahim et al. (2008) which involved twenty subjects from a school in Malaysia focused on helping children to resolve conflict in communication. The subjects were twelve years old male and female students. Six chosen extracts that were related to the study were analysed and the results of the study had given guides for teaching conflict resolution for the children where the children's' emotions need to be calmed down, let children give their side of the story without interruption, help the children to name the problem and try to see the point of view of others and lastly brainstorm possible solutions and then decide which solution and adjust as needed. According to Fittro (2007), children develop at different rate but a child's age may help you know their general capabilities. Therefore, each child has its own specialities and capabilities and hence each child will be able to contribute their style of learning in the classroom.

Arif et al. (2009) proclaim that lack of communications or distorted communication opens up to disharmony and conflict in the individual life as well as practices in the organizations. They claim that each individual spends his/her maximum time in communicating therefore it is accentuated that communication encounters major activity of a human being is controlled in an accepted manner. This would therefore lead to a smooth life. Hence, Franklin (2005) postulates that an effective communicator avoids a series of quick-fix tricks of techniques. Franklin's statement reflects the techniques done by younger communicators where they try to avoid the use tricks of techniques in their conversation and as long as the message can be delivered, they were contented. This also reflects the distractions in communication where at times they have to distract themselves in order to continue with the rest of the conversation (Hill, 2009).

The objectives of the study are:

- To identify the theme of the distraction in communication during interaction.

- To discuss the distraction in communication during interaction. 
INTERNATIONAL JOURNAL OF ACADEMIC RESEARCH IN BUSINESS AND SOCIAL SCIENCES Vol. 10, No. 10, 2020, E-ISSN: 2222-6990 @ 2020 HRMARS

\section{Methodology}

A total number of twelve subjects participated in this study. The subjects were students from a Media Creative subject from Bluecoat Technology College, Nottingham United Kingdom. The subjects were in groups of fours and they were given a task which involved the discussion of a video project. The meetings and discussion took place for six weeks and three hours per week. They were to write and design the storyboard for the video clip. The discussion was videoed and taped and the distraction arose during the discussion were discussed. The discussion was analysed by using the discourse analysis theory by Rahim (2020a). According to Rahim (2020a), in discourse analysis theory there are three elements involved. They are content, context and assumption. However, this study will only focus on the last element which is assumption in analysing the data. Rahim (2020a) also mentioned that assumption in discourse is considered as something that are true or certainly will happen without the need to provide any proof. In other word, assumption is also something that is considered true without evidence needed. This is accepted in assumption in discourse. Occasionally, assumptions are made in a way that something will really happen.

\section{Results and Discussion}

SIGHT distraction in communication.

All groups seemed to be very excited with the project. They started off with writing and designing of the layout of the storyboard. They were seen discussing and once they were saw the other group laughing, they were distracted. They were asking questions that were not related to the project such as, 'Why are they laughing?', 'What are they talking about?', 'Why are the groups not discussing about the project?' and 'Why is it so interesting until they had to laugh?'. Most of the questions were not answered by the group members since they were only looking at the group and they stopped the discussion when they heard the other group laughing and giggling. Hence, there were also distractions in communication when they saw a few students with their new i-pad and they were seen gathered to see the new i-pad. They were communicating with each other such as, 'This is really cool!', 'Wow, really expensive this one is!', 'How much is it?', 'Hey, look. Touch screen!', 'Is it heavy?' and 'Fantastic this one is. I want one'. There were other similar questions by other students and a number of the students were seen trying to touch the screen of the new i-pad. They continued with the discussion after there were more people around and they felt a bit squashed so they went back to their places.

Apparently, a lady came in the classroom. It seemed that the lady is the clerk from the main office. The lady were seen talking to the teacher and the students automatically stopped with the discussion since they were really want to know about the visit since they had not many visitors from the office. The students were seen talking to each other in their own groups but most of the interactions were on the visitors from the office like, 'The principal wants to see you now!', 'This must be really important.', 'What have you done now?', 'Did I leave something in the office just now?', 'She looks so serious!' and 'She doesn't look angry so it is not serious!'. The students were trying to make assumptions and they were also trying to joke out of the matter with each other about the visitor. When the visitor left, the students continued with their discussion and the discussion about the visitor

had gone totally. In other occasion, the students were distracted with the weather. At that time, the first snow was seen and they were so excited with the snow since they saw the snow from the window in the classroom. They stood up and gathered near the window and they were seen communicating 
INTERNATIONAL JOURNAL OF ACADEMIC RESEARCH IN BUSINESS AND SOCIAL SCIENCES Vol. 10, No. 10, 2020, E-ISSN: 2222-6990 @ 2020 HRMARS

with each other about the snow such as, 'Oh my gosh, its snowing!', 'I love it when it snows. It looks so lovely.', 'Shall we go out later to play with the snow?', 'I will never get bored with the snow.', and 'I wish it will snow until a few days so that the college will be closed!'. It can be seen that the students were happy with the snow and they had stopped with the discussion. Their conversations were merely on the snow and some of the interactions were similar since they were talking about the snow. At times they were seen laughing and giving body gestures like snowboarding or skiing and even they showed the gestures of sliding and falling down. Therefore, there was sight distraction in communication that took place during the discussion of the project.

\section{HEARING distraction in communication.}

Besides having sight distraction in communication, there was also hearing distraction in communication. The students were distracted with whatever they heard during the project discussion.

There were questions pertaining to what they heard such as, 'What was that?', 'What is the title of that song?', 'Can you hear it?', 'Why such loud sound?' 'What have you done now?' and 'Was that your lap-top?. They questions were merely showed that they were worried, puzzled or shocked with what they heard. They were distracted with the sound and had stopped with the discussion of the project. Apart from the questions that they asked, the students also commented on the hearing distraction that they heard such as, 'I heard that her voice is husky.', 'She lost her voice totally just now.', 'I hate it when she drags her shoes like that!', 'What's with that growling sound from your tummy?', 'I want to listen to that song again. Rewind please!', and 'What are they discussing about over there?'. The statements and questions were actually from what they heard and the distraction had made them stopped discussing for a while. They were looking at the objects or place and they were talking about it with their friends from the group or from other groups. Besides the sound that they heard within the classroom, the students were also distracted in communication during the project discussion when they heard the sound from outside the classroom such as, 'The class next door must be having a good time now!', 'I wish we can laugh out loud like them in the next class!', 'I just totally forgotten on how to laugh out loud!', 'Can you hear the footsteps? That must be the teacher now!', 'Hey, listen! Can you hear the music?' and 'Shall we join the party next door!'. The questions and statements were merely on the sound that they heard. At times they were giving signal to stop talking so that they will be able to continue with their listening but at times the sounds were so loud that all the groups stopped discussing and smiling. They were happy to be part of the happy group next door and they were seen walking to the wall in order to continue listening.

\section{MIND distraction in communication.}

Apart from sight and hearing distraction in communication, the students seemed to have another kind of distraction when discussing the project. Mind distraction has the most distraction in communication among the other two since the students were distracted all the time during the project discussion. The distractions like, 'Guess what? I had a weird dream last night!', 'I never had a dream all my life!', 'I forgot where I put my new CD that I bought yesterday.', 'I baked a cake yesterday, you know!', 'I wish I have extra allowance this month.', 'Shall we go out to the city this Saturday?' and 'I want to buy that same bag that you have there!'. Most of the interactions were based on personal statement that crossed their mind during the project discussion. The students wanted to share whatever crossed their mind with their friend and hoping to have response with 
their statements. Some of the statements were responded but some of them were ignored. If it was ignored, there will be a long silence with the students busy looking at the layout of the storyboard that they were discussing or at times they were looking elsewhere with their lingering mind. The mind distraction was sometimes referred to their friends in the group, such as 'Did you manage to buy that ear ring that you like?', 'Where did you put the folder that I gave you last?, 'Did the teacher see you yesterday?, 'I want to buy that wallet exactly like yours.', 'I like you shoes, let me try!', 'Give me that girl's mobile number!' and 'Put your glasses on! You can't even read that advertisement.' The questions and statements by the students were meant to have response and feedback from their friends and therefore, the project discussion was stopped due to the mind distraction. Besides having mind distraction among the group members, the students were seen having distractions with the other group members and the teacher. The students were seen going to the other tables or talking to the teacher such as, 'Hey, did you get my text message last night?', 'Where did you got yesterday?', 'Hey, stop blabbering and start talking sensibly!', 'Did you go out last weekend? I tried to call you!', 'Miss, I like you shoes!', 'Miss, did you go to that new shop in the city?', 'Miss, have you seen that new video clip on MTV?' and 'Miss, do you like Indian cuisine?'. The questions and statements were from the students' mind distraction during the project discussion.

The students were seen not concentrating with the project and interactions between the group members and other groups as well as the teacher were clearly heard. The students were went back to the discussion when there were no response from their friends or teacher or even the students were reminded by the teacher to get back to the project.

\section{Summary of Results}

Mostly all the students were distracted in communication during the project discussion. The results were parallel with the research done by Franklin (2005). The students were sight distracted in communication, hearing distracted in communication and lastly mind distracted in communication during the project discussion. The students were either murmuring to themselves, interacted with their group members, interacted with the other group members or even to the teacher in the classroom. The distractions had made them able to give good ideas towards the project since the distraction had made them have new ideas in mind and able to give contribution towards the projects. The results were similar with the research done by Arif et al. (2009). Although they were always reminded to get back to the project but still they had made the discussion and the project a successful activity. With the distractions, the students managed to work and collaborate really well with their group members. Amiruddin et al.(2019) also agreed with this study where communicative strategies are enhanced based on social stories and it can also provide opportunities for language users in using strategies for effective communication purposes. This study is similar to a study by Rahim et al. (2017) where interaction tend to give confusion among learners especially during language learning communication. This study is parallel with a study by Rahim (2020d) where discourse study is desirable in giving deep meaning to the content of speech, interaction, text and writing. Discourse studies can have an impact in the form of a clearer understanding among language users.

\section{Conclusion}

Communication distractions had made the students able to finish the project with satisfaction and successfully. The students were happy and contented with the projects since they did have the 
INTERNATIONAL JOURNAL OF ACADEMIC RESEARCH IN BUSINESS AND SOCIAL SCIENCES Vol. 10, No. 10, 2020, E-ISSN: 2222-6990 @ 2020 HRMARS

pressure or stressed out with the discussion and the process of discussing had given a positive impact towards learning. This study resulted a positive outcome with the distraction in communication among college learners at Bluecoat Technology College and at the same time able to create interest towards learning. Therefore, it is hoped that the educators and administrators were given the input on the positive side of having distraction in communication and at the same time giving advice to students to actively involved in group discussion.

This study contributes to the ministry of higher education and universities in designing curriculum that is suitable for students at tertiary level. On the other hand, this study also contributes towards university students and enhance their learning. Besides, the students will be motivated in learning new things in a very conducive environment. Students will be contempt and satisfied with the learning environment and they will contribute more during class activities.

\section{References}

Abigail, R., \& Cahn, D. (2011). Managing Conflict Through Communication. Allyn and Bacon: USA

Braedyn, S., Makenzie, A., Tannen, D., \& Coleman, M. (2010). Gender Communication Differences: Childhood Communication. Retrieved on 16 March 2012 from http://amandamakenziebraedynsvecz.suite101.com/gender-communicationdifferences childhood-communication-a297967.

Cahn, D. (2006). Managing Conflict through Communication (3rd Edition). Allyn and Bacon: USA

DeVito, A. (2009). The interpersonal communication book. 12th ed. Boston: Allyn \& Bacon.

Fittro, J. (2007). Resolving conflict. Family Community Leadership Project. Washington State University Cooperative Extension.

Floyd, K. (2008). Interpersonal communication: The whole story. New York: McGraw-Hill.

Franklin, K. (2005). Special Strategies for Small Language Groups: Part 1: Rethinking Stories. International Journal of Frontier Missions, 22 (1), 6-12.

Hill, H. (2009). From One Mind to Another. In Rodica Dimitriu and Miriam Shlesinger (eds.), Translators and their readers in homage to Eugene A. Nida, (pp. 97-111). S.I.: Les Éditions du Hazsard.

Mansor, N., \& Rahim, N. A. (2019). Eh! Media Sosial. Universiti Malaysia Terengganu: Penerbit Universiti Malaysia Terengganu.

Rahim, N. A., Sujud, A., Subramaniam, V., Affendi, N. R. N. M., \& Hamzah, Z. A. Z. (2008). Helping Children Resolve Conflict in Communication. The International Journal of Learning, 15 (15), 137-142.

Rahim, N. A. (2011a). Disturbance in Storytelling Session Among Asperger Children. Jurnal Persatuan Linguistik Malaysia (in Malay), 35-42.

Rahim, N. A. (2011b). Music Video Clip Storyboard Writing among Focus Group Learners of Media. Global Media Journal Malaysian Edition, 1, 24 - 33.

Rahim, N. A. (2019). Kajian Wacana dan Strategi Komunikasi: Teori dan Aplikasi. Universiti Malaysia Terengganu: Penerbit Universiti Malaysia Terengganu.

Rahim, N. A. (2019). Multimedia dalam Bahasa. Universiti Putra Malaysia: Penerbit Universiti Putra Malaysia.

Rahim, N. A., \& Harun, N. I. (2016). Students' Perception towards Malay Folklore Songs. Springer Science and Business Media Singapore 2016 Regional Conference on Science, Technology and Social Sciences (RCSTSS 2014). DOI 10.1007/978-981-10-1458-1_59, 641-648. 
INTERNATIONAL JOURNAL OF ACADEMIC RESEARCH IN BUSINESS AND SOCIAL SCIENCES

Vol. 10, No. 10, 2020, E-ISSN: 2222-6990 @ 2020 HRMARS

Rahim, N. A., Halim, H. A., Mamat, R., \& Mansor, N. S. (2016). Malay Folklore Discourse among Korean Students. Jurnal Kemanusian, 25 (1), 12-21.

Rahim, N. A., Halim, H. A., Mamat, R., Mansor, N. S., \& Roslan, S. N. A. (2017). Confusion in Interaction among Korean Learners. Journal of Business and Social Development. 5 (10), 18-24.

Rahim, N. A., Pawi, A. A. A., \& Affendi, N. R. N. M. (2018). Integration of Values and Culture in Malay Folklore Animation. Pertanika J. Soc. Sci. \& Humanities, 26 (1): 359 - 374.

Rahim, N. A. (2020a). Kajian Wacana dan Penerimaan Teknologi. Serdang: Penerbit Universiti Putra Malaysia.

Rahim, N. A. (2020b). Perspektif Teknologi Digital. Serdang: Penerbit Universiti Putra Malaysia.

Rahim, N. A. (2020c). Spek[c]trum Penyelidikan. In Normaliza Abd Rahim(Ed). Spek[c]trum Penyelidikan: Teori dan Aplikasi (pp. 1-6) Terengganu: Penerbit Universiti Malaysia Terengganu.

Rahim, N. A., Roslan, S. N. A., Roslan, N. M., \& Roslan, N. W. (2020). The Effects of Climate Change. In Normaliza Abd Rahim (Ed). Spek[c]trum Penyelidikan: Teori dan Aplikasi (pp. 189-196). Terengganu: Penerbit Universiti Malaysia Terengganu.

Rahim, N. A. (2020d). Kajian Wacana. In Normaliza Abd Rahim (Ed). Penyelidikan Wacana; Teori dan Aplikasi (pp. 1-7). Terengganu: Penerbit Universiti Malaysia Terengganu.

Arif, M., Jam, K., Maswat, Z. A., \& Ullah, I. (2009). Performance Enhancement through Effective Communication: A Study of the Role of External and Internal Communication. Interdisciplinary Journal of Contemporary Research in Business, 1 (7), 119-148.

Amiruddin, S., Rahim, N. A., Halim, H. A., \& Jalaludin, I. (2019). Social Stories to Enhance Communicative Strategies Among Autism Spectrum Disorder (ASD) Children. Jurnal Komunikasi: Malaysian Journal of Communication, 35(2), 87-102.

Tingley, J. C., Tannen, D., Herrmann, N., Hersey, P., \& Kenneth, H. B. (2006). General Communication. Retrieved on 16 May 2012 from http://www.cacubo.org/proDevOpp/Gender\%20Communication.pdf.

Wood, J. (2010). Interpersonal communication: Everyday encounters, 6th ed. Boston: Wadsworth. 